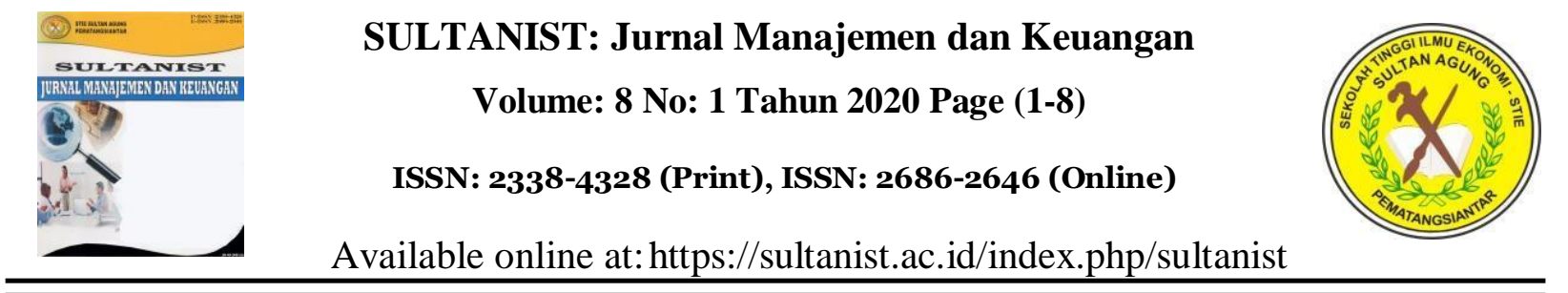

\title{
PENGEMBANGAN SDM UNGGUL BERBASIS COLLABORATIVE STRATEGIC MANAGEMENT
}

\author{
Maria Apsari Sugiat \\ Universitas Telkom, Jl. Telekomunikasi No. 1, Bandung, Jawa Barat 40257, Indonesia \\ mariasugiat@telkomuniversity.ac.id
}

\begin{abstract}
Abstrak
Perubahan paradigma dari Human Resources menjadi Human Capital Development di era digital saat ini, mengharuskan terjadinya sinergi diantara pemangku kepentingan dalam membangun negara. Sehubungan dengan citacita membangun keberlanjutan masyarakat yang unggul, terdapat dua pendekatan yang berbeda dalam pelibatan pemangku kepentingan untuk mengimplementasikan rencana yang sukses, yaitu partisipasi dan kemitraan. Dua hal ini bentuk kolaborasi yang berbeda, perlu disesuaikan dengan kondisi daerah seperti potensi SDM, potensi infrastruktur, dan potensi lainnya. Jenis pendekatan kemitraan dan kolaborasi menjadi pendekatan yang sangat ideal untuk rencana keberlanjutan masyarakat. Terutama tingkat keterlibatan yang tinggi dari pemangku kepentingan organisasi, seperti pemerintah daerah bekerjasama dengan para pemangku kepentingan dalam insiatif membangun SDM berkelanjutan. Sehingga perlu muncul collaborative strategic management dalam melibatkan pengambilan keputusan dan strategi bersama untuk memasukan ide-ide dari berbagai pemangku kepentingan ke dalam pengembangan rencana keberlanjutan masyarakat. Rencana ini melibatkan mitra utama dalam mengimplementasikan dan berkomitmen terhadap tujuan koletif dan tindakan yang akan dilaksanakan bersama. Tujuan dalam penelitian ini bagaimana membangun SDM unggul baik dari private sector maupun public sector melalui pendekatan collaborative strategic management dan pendekatan human capital development, dengan menghasilkan beberapa temuan dan rekomendasi. Penelitian ini menggunakan metode deskriptif eksploratif, memanfaatkan data literatur dan data-data yang ada dilapangan baik online maupun offline. Hasil penelitian ini adalah rekomendasi pola kemitraan dalam meningkatkan kemampuan sumber daya manusia unggul termasuk melibatkan pemangku kepentingan melalui collaborative strategic management, agar mencapai tujuan yang kolektif dan maju bersama.
\end{abstract}

Kata kunci: Collaborative, SDM unggul, Strategic Management

\section{DEVELOPING SUPERIOR HUMAN RESOURCES BASED ON COLLABORATIVE STRATEGIC MANAGEMENT}

\begin{abstract}
The paradigm alteration from Human Resources to Human Capital Development in the current digital era, requires a synergy among stakeholders in developing the country. In connection with the ideals of building superior community sustainability, there are two different approaches to stakeholder engagement to implement a successful plan, namely participation and partnership. These two different forms of collaboration need to be adjusted to local conditions such as HR potential, infrastructure potential, and other potential. This type of partnership and collaboration approach is the ideal approach for community sustainability plans. Especially the high level of involvement of organizational stakeholders, such as local governments in collaboration with stakeholders in initiatives to build sustainable human resources. So that collaborative strategic management needs to appear in involving joint decision making and strategies to include ideas from various stakeholders in the development of community sustainability plans. This plan involves key partners in implementing and committing to the collective goals and actions that will be implemented together. The purpose of this research is to obtain several findings and recommendation on how to build superior human resources from both the private sector and public sector through a collaborative strategic management approach and the human capital development approach The method used in this research is exploratory descriptive, utilizing literature data and existing data both online and offline.. The result of this research is recomendation that in enhancing superior human resources it needs a partnership pattern in its development, including stakeholder involvement to achieve collective goals and progress.
\end{abstract}

Keywords: Collaborative, Superior Human Resources, Strategic Management 


\section{PENDAHULUAN}

Perkembangan teknologi mengakibatkan terjadinya perubahan kebutuhan Sumber Daya Manusia di masyarakat. Teknologi digital dalam 20 tahun terakhir ini merubah beberapa lapangan pekerjaan yang saat ini dilakukan oleh tenaga manusia. Sekitar 30 persen tugas dari dua pertiga jenis pekerjaan memungkinkan dapat digantikan oleh teknologi, seperti robot atau kecerdasan buatan (artificial intelegence) (Allen, 2015). Disrupsi lapangan kerja dan meluasnya otomatisasi mengharuskan Indonesia memiliki SDM yang unggul, diantaranya adalah kemampuan berkolaborasi antara manusia dengan robot, kemampuan mengontol dan kendali jarak jauh (remote system), manajemen kinerja digital dan otomasi pengetahuan kerja. Pembangunan Sumber Daya Manusia perlu kerjasama yang sinergi antar pemangku kepentingan. Pembangunan di Indonesia mengalami perubahan paradigma, adanya industri 4.0 ini sebagai fase revolusi teknologi mengubah cara beraktifitas manusia dalam skala, ruang lingkup, kompleksitas dan transformasi, tidak saja pengembangan aspek ekonomi, sosial dan lingkungan saja, akan tetapi kolaborasi menjadi aspek yang terpenting saat ini, seperti aspek sosio-ekonomi, aspek ekonomilingkungan, dan aspek lingkungan sosial.

Perubahan paradigma ini berdampak kepada perubahan kebutuhan keahlian di lapangan pekerjaan di masa depan, dimana perlunya keseimbangan antara hard-skill dan soft-skill. Peningkatan SDM unggul menjadi target yang harus dicapai oleh pemerintah untuk mempersiapkan pondasi yang kokoh dalam membangun ekonomi negara, karena melalui SDM berkualitas merupakan kunci menuju negara berpendapatan tinggi. Paradigma lain muncul juga pergeseran dari human resources menjadi human capital development untuk mempersiapkan SDM yang handal di era digitalisasi saat ini.

Era 4.0 merupakan fase revolusi teknologi yang mengubah manusia dalam beraktivitas dan bahkan ketidakpastian global. Di sisi lain manusia dituntut memiliki kemampuan dalam memprediksi masa depan yang progresif dengan merespon perubahan tersebut secara terintegrasi dan komprehensif, termasuk melibatkan unsur politik global, sektor publik dan swasta dan akademisi.

Namun dari semua paradigma yang ada perlu sinergi dan kerjasama dalam membangun SDM yang diperlukan sesuai dengan tujuan yang kolektif dan berbagai pemangku kepentingan. Sehubungan dengan cita-cita membangun keberlanjutan masyarakat yang unggul, terdapat dua pendekatan yang berbeda dalam pelibatan pemangku kepentingan untuk mengimplementasikan rencana yang sukses, yaitu partisipasi dan kemitraan. Dua hal ini bentuk kolaborasi yang berbeda, perlu disesuaikan dengan kondisi daerah seperti potensi SDM, potensi infrastuktur, dan potensi lainnya.

Dalam menghadapi era distruptif teknologi, manusia harus mampu mengubah cara beraktivitasnya baik dalam skala, ruang lingkup, kompleksitas dan transformasi dari pengalaman sebelumnya. Kemampuan untuk dapat berubah dengan cepat dan memiliki kemampuan prediksi masa depan menjadi solusi manusia dalam menghadapi kehidupan yang tidak pasti (uncertainty). Dukungan dari pemangku kepentingan dari mulai sektor publik, swasta, akademisi hingga masyarakat menjadi peluang yang terintegrasi dan komprehensif dalam menghadapi tantangan industri 4.0.

Tantangan yang berat bagi bangsa Indonesia adalah daya saing dan tingkat pengangguran terbuka Indonesia mencapai $5,33 \%$ atau 7,01 juta jiwa dari total 131,55 juta orang angkatan kerja pada bulan februari 2017 (Badan Pusat Statistik, 2017). Tantangan lainnya ditambah lagi oleh tuntutan kebutuhan industri, dimana pasar kerja membutuhkan sumber daya manusia multi-skill dan juga adanya bonus demografi yang akan terjadi pada tahun 2030-2040, yaitu penduduk dengan usia produktif akan lebih banyak dibandingkan dengan penduduk non-produktif dengan perkiraan mencapai $64 \%$ dari total penduduk Indonesia.

\section{LANDASAN TEORI}

\section{Perubahan paradigma dalam pembangunan Indonesia}

Secara fundamental perkembangan 


\section{SULTANIST: Jurnal Manajemen dan Keuangan, Vol 8 (1), 2020}

Industri 4.0 telah membawa perubahan besar dalam kehidupan manusia dan mengubah cara beraktivitas serta membawa pengaruh besar terhadap dunia kerja. Dampak positif industri 4.0 antara lain adanya efektifitas, efisiensi sumber daya dan biaya produksi, namun sisi lainnya terjadi konsekuensi adanya pengurangan lapangan pekerjaan. Tuntutan industri 4.0 membutuhkan tenaga kerja yang terampil dalam literasi digital, teknologi dan manusia (Suwardana, 2018).

Jutaan jenis pekerjaan baru diperkirakan muncul dalam satu dekade ke depan seiring perkembangan teknologi otomatisasi dan kecerdasan buatan. Untuk itu, Indonesia perlu mempersiapkan transisi keterampilan (skill) yang akan nantinya bisa mengadopsi teknologi. Menurut analisa McKinsey \& Company pada tahun 2015, ekonomi Indonesia pada 2030 mendatang diproyeksikan menciptakan pekerjaan baru yang sebelumnya tidak pernah ada, dan berdampak mendorong peningkatan pendapatan, pembangunan infrastruktur, anggaran teknologi, konsumsi dan peningkatan pertumbuhan ekonomi (Allen, 2015). Tipe pekerjaan yang akan tumbuh di masa depan adalah kearah layanan (service) seperti pemrosesan data dan pekerjaan fisik yang dapat diperkirakan.

\section{Sumber Daya Manusia dan Era Digital}

Pada Era ini manusia bukan lagi dianggap sebagai barang yang statis dan hanya diperhitungkan aspek operasional dan kesejahteraannya semata, tetapi harus menjadi asset kritis yang tidak dapat dijiplak (bukan mesin) karena telah terjadi perubahan tatanan, sehingga muncul paradigma lain yaitu pergeseran dari human resources menjadi human capital (Armstrong, 2008).

Kemajuan bangsa saat ini ditentukan oleh persoalan sumber daya manusia, dimana SDM Indonesia masih berada di level yang cukup rendah. Hanya sebagian kecil saja masyarakat Indonesia yang berpendidikan tinggi. Indonesia termasuk empat negara besar jumlah penduduknya yang terdiri dari multikultural dan tinggal diberbagai pulau dengan terpisahkan oleh ruang, jarak dan waktu. Jumlah penduduk besar ini mayoritas di rentang usia 15-64 tahun dan ini sering disebut sebagai bonus demografi, dimana mendorong pertumbuhan ekonomi dan pendapatan perkapita. Teknologi digital akan berdampak terciptanya 3,7 juta pekerjaan baru dalam kurun waktu 7 tahun mendatang dan mayoritas jenis pekerjaan adalah jasa (Suwardana, 2018). Hal ini menjadi tantangan untuk meningkatkan keahlian diri serta inovasi berkelanjutan.

Perubahan pola pikir (mindset) dan cara bersikap (behavioural approach) akan mewujudkan mentalitas yang baik dan terbentuk dalam perilaku. Tidaklah mudah melakukan perubahan pola pikir yang menghasilkan penguatan karakter mental dan keahlian. Menaikan derajat kompetensi diri dan potensi diri secara linear akan melahirkan masyarakat sejahtera, berkualitas dan unggul.

\section{Sumber Daya Manusia}

Sumber daya manusia merupakan sumber daya manusia yang menggerakan organisasi atau perusahaan untuk menghasilkan barang dan jasa. Jika kualitas sumber daya manusia masih relatif rendah, maka besarnya jumlah penduduk walau dengan struktur proporsi usia produktif juga dapat menjadi ancaman. Terutama di tengah perubahan orientasi memenangkan pasar dan sikap budaya instan. Disamping itu human resources adalah lembaga atau departemen yang bertanggung jawab mengatur sumber daya manusia di perusahaan maupun organisasi. Di Indonesia pengembangan sumber daya manusia dilaksanakan melalui pendidikan yang memiliki literasi lama, literasi baru dan literasi teknologi yang terkait dengan paradigm pembangunan aspek sosio-ekonomi, aspek ekonomi-lingkungan dan aspek lingkungan sosial seperti pada Gambar 1 berikut. 


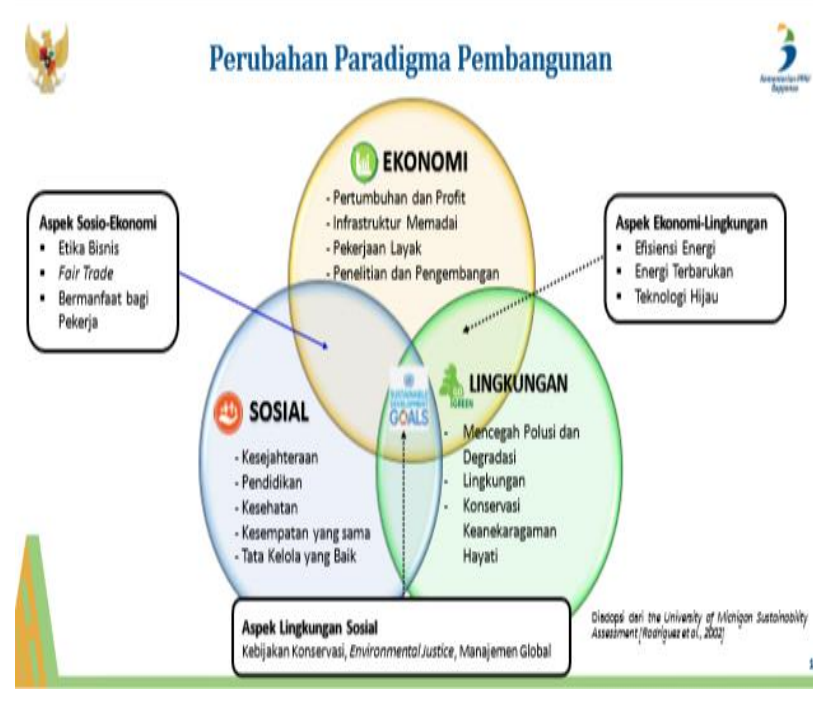

Gambar 1. Skema Perubahan Paradigma Pembangunan

\section{Pengembangan Sumber Daya Manusia}

Pada Era digital yang akan menciptakan digital ekonomi, human resources menjadi kunci utama dalam menciptakan keunggulan bersaing dan efisiensi dalam perusahaan atau organisasi, dimana pengetahuan dan keahlian (skill) serta kemampuan komunikasi (communication) dengan pelanggan merupakan aspek penting dalam human capital, yang menggambarkan sejumlah pengetahuan, keahlian, kreatifitas dalam bersaing. Dengan demikian Sumber Daya Manusia diperlakukan sebagai aset produktif bukan sebagai biaya sebagaimana mesin dan bahan baku (Hendricks, 2002). Human Capital bukan sekedar masukan dalam sebuah proses, namun memainkan peran yang lebih kompleks dalam memproses barang dan jasa. Human Capital berhubungan dengan pengetahuan, pendidikan, kompetensi dan evaluasi pshychometric (Namasivayam \& Denizci, 2006). Karakteristik human Capital ini membawa ke sebuah situasi ekonomi yang dinamis (Menzies, 2003). Saat ini pertumbuhan dan kontirbusi Human Caiptal dalam Produk Domestik Bruto meningkat pesat, sehingga Human Capital dapat didefinisikan sebagai sekumpulan atribut, life trade, pengetahuan, kreativitas, inovasi dan energy yang diinvestasikan orang dalam pekerjaannya (Weatherly, 2003).

Perubahan paradigma ini berdampak kepada perubahan kebutuhan keahlian di lapangan pekerjaan di masa depan, dimana perlunya keseimbangan antara hard-skill dan soft-skill. Peningkatan kemampuan SDM menjadi Human Capital merupakan target yang harus dicapai oleh pemerintah untuk mempersiapkan pondasi yang kokoh dalam membangun ekonomi negara, karena melalui SDM yang memiliki pengetahuan, keterampilan, kreatif, mampu berinovasi dan berkomunikasi dengan ahlak yang baik merupakan kunci menuju negara berpendapatan tinggi.

Berdasarkan UU RI No.20 Tahun 2003 tentang Sisdiknas Bab II pasal 3 menyebutkan bahwa Pendidikan nasional memiliki fungsi untuk mengembangkan kemampuan dan watak dalam menciptakan peradaban bangsa. Demi tujuan tersebut terjadinya teknologi 4.0 diharuskan adanya penguatan jati diri bangsa Indonesia dalam menghadapi globalisasi.

Human Capital Development untuk mempersiapkan SDM menjadi Human Capital yang handal di era digitalisasi saat ini. Namun dari semua paradigma yang ada, perlu sinergi dan kerjasama dalam membangun SDM yang diperlukan sesuai dengan tujuan yang kolektif dan berbagai pemangku kepentingan. Sehubungan dengan cita-cita membangun keberlanjutan masyarakat Indonesia yang sanggup bertahan dan siap bersaing di Era Dijital ini dan sanggup meningkatkan ekonomi dijital di Indonesia.

\section{Collaborative Strategic Management}

Menurut data dari EMSI, Oxford Economic Forecasting, US Bureau of Labor Statistics, dalam analisis McKinsey pada tahun 2015, menunjukan bahwa $51.8 \%$ potensi kehilangan pekerjaan, dimana teknologi mendorong terciptanya jenis pekerjaan baru yang lebih produktif dan jumlahnya besar (Allen, 2015). Fenomena ini menunjukan bahwa begitu rentannya pekerjaan-pekerjaan yang ada sekarang, jika tidak dipersiapkan secara kolaborasi dan strategis. Sehingga perlu collaborative strategic management dalam melibatkan pengambilan keputusan dan strategi bersama untuk memasukan ide-ide dari berbagai pemangku kepentingan ke dalam pengembangan rencana keberlanjutan masyarakat. Rencana ini melibatkan mitra 


\section{SULTANIST: Jurnal Manajemen dan Keuangan, Vol 8 (1), 2020}

utama dalam mengimplementasikan dan berkomitmen terhadap tujuan kolektif dan tindakan yang akan dilaksanakan bersama dalam memahami aspek sosial, ekonomi dan lingkungan. Karena akumulasi pengetahuan dan keterampilan human capital berhubungan langsung dengan efisiensi. Pada negara-negara maju PDB meningkat secara linier seiring dengan pelatihan dan pendidikan masyarakat. Sehingga akumulasi human capital dapat meningkatkan taraf hidup, kesehatan masyarakat dan mengurangi tingkat kriminalitas yang pada akhirnya akan meningkatkan pertumbuhan ekonomi dalam jangka panjang (Carmeli \& Schaubroeck, 2005). Terdapat dua jenis pendekatan dalam pengembangan sumberdaya manusia, yaitu 1). Partisipasi dan 2). Kemitraan.

\section{Partisipasi}

Terdapat dua pendekatan yang berbeda dalam pelibatan pemangku kepentingan untuk mengimplementasikan rencana yang sukses, yaitu partisipasi dan kemitraan. Konsep partisipasi adalah keterlibatan para pihak dalam jangka pendek dengan keterlibatan yang tidak mendalam. Pendekatan partisipasi dapat dipakai bagi pengembangan sarana pendidikan seperti gedung dan peralatan pendidikan terutama bagi lokasi yang jauh dari pusat kota. Disamping itu, partisipasi pada pelatihan jangka pendek untuk meningkatkan keahlian dan kemampuan SDM yang sudah memiliki ilmu pengetahuan dasar menjadi sangat efektif dan efisien. Karena memiliki potensi SDM yang baik namun tidak memiliki infrastruktur pendidikan, jalan dan telekomunikasi yang baik. Namun dalam konsep pengembangan pengetahuan, keterampilan dalam jangka panjang diperlukan konsep kemitraan, Terutama tingkat keterlibatan yang tinggi dari pemangku kepentingan organisasi, seperti pemerintah daerah bekerjasama dengan para pemangku kepentingan dalam insiatif membangun SDM keberlanjutan.

\section{Kemitraan}

Konsep Kemitraan dimulai dari beberapa industri konstruksi di Amerika yang ditulis oleh Constrution Industry Institute pada tahun 1991 bersama dengan The Associated General
Contractor of Amerika, sedangkan di Inggris informasi mengenai kemitraan dipublikasikan oleh Chartered Institute of Building Services Engineer pada tahun 1995 yang ditunjuk untuk meningkatkan kinerja proyek industri konstruksi kemitraan sebagai komitmen jangka panjang antara 2 atau lebih organisasi untuk mencapai tujuan tertentu dengan memanfaatkan secara efektif sumber daya para pihak yang bekerjasama untuk menciptakan kinerja yang optimal, daya saing dan perbaikan barang dan jasa (Cheng et al., 2000). Sedangkan istilah yang dipakai menurut pendapat Wheelen dan Hunger (2012), strategi kooperatif digunakan oleh perusahaan untuk mencapai keunggulan bersaing dalam industri dengan cara bekerja sama dengan perusahaan lain. Thomas Piketty (2014), ekonom asal Perancis, dalam bukunya Capital in the Twenty-First Century, telah mengingatkan pentingnya ketiga aktor: pengusaha/industri, civitas akademika/perguruan tinggi dan pemerintah bekerja sama dalam merespons perubahan. Kebijakan sistem pendidikan, akses terhadap perkembangan ilmu pengetahuan (untuk memperoleh keterampilan-keterampilan khusus), serta sistem kelembagaan di bidang pendidikan menjadi kunci bagaimana suatu negara mampu beradaptasi dengan transformasi industri yang sangat cepat. Piketty (2014) juga menyebutkan bahwa difusi pengetahuan bergantung pada kemampuan suatu negara memobilisasi pembiayaan untuk mendorong investasi skala besar di sektor pendidikan, penelitian dan pelatihan serta menjamin kerangka hukum yang stabil. Korea Selatan melakukan kerja sama antara universitas dan industri dalam merestrukturisasi kurikulum yang diarahkan agar pelajar dapat mengerti bagaimana teori yang mereka pelajari dapat diterapkan di industri serta apa saja pengembangan skill dan penguasaan teknologi yang dibutuhkan di area industri. Serta memberikan wadah untuk menghubungkan universitas dan perusahaan, melalui programprogram seperti Industry- University Cooperation dan Industry-University Partnership Professors (Koschatzky \& Stahlecker, 2010).

\section{METODE PENELITIAN}

Metode penelitian yang dipilih adalah 


\section{SULTANIST: Jurnal Manajemen dan Keuangan, Vol 8 (1), 2020}

deskriptif analisis, dimana metode ini adalah berfungsi untuk mendeskripsikan atau memberikan gambaran terhadap objek yang diteliti melalui data atau sampel yang terkumpul sebagaimana adanya tanpa melakukan analisis dan membuat kesimpulan yang berlaku untuk umum (Sugiyono, 2017). Permasalahan dalam penelitian ini memusatkan kepada masalah sebagaimana ada pada data sekunder, kemudian hasil penelitian dan analisis diolah untuk mengambil keputusan. Maka untuk mendapatkan collaborative strategic management diambil analisisnya dari data lapangan mengenai fenomena peningkatan modal manusia untuk menghadapi revolusi industri 4.0 dari Kementrian Perencanaan Nasional / Kepala Badan Perencanaan Pembangunan Nasional. Penelitian ini menggunakan metode deskriptif analisis dimana untuk mengetahui fenomena yang saat ini terjadi dan ditarik kesimpulan sebagai sebuah rekomendasi.

\section{HASIL DAN PEMBAHASAN}

Dalam mencapai target Visi Indonesia 2045, dimana 100 tahun Indonesia merdeka, dibutuhkan tenaga sumber daya manusia yang kompeten. Perencanaan strategis diperlukan untuk dapat membangun manusia Indonesia seutuhnya dengan cara mengenal terlebih dahulu potret modal manusia Indonesia. Visi Indonesia 2045 terdapat 4 pilar pembanguan tahun 2045, yaitu 1). Pembangunan Manusia dan Penguasaan Iptek, 2). Pembangunan Ekonomi yang berkelanjutan, 3). Pemerataan Pembangunan, 4. Pemantapan Ketahanan Nasional dan Tata Kelola Kepemerintahan, demi mewujudkan Indonesia yang berdaulat, maju, adil dan Makmur. Selain 4 pilar diatas, Indonesia memiliki target peningkatan PDB dari semula USD 3,877 tahun 2017, lalu USD 13,162 tahun 2036 dan target akhir di tahun 2045 PDB perkapita USD 23,199. Tentunya target harus dapat tercapai melalui strategis manajemen yang sifatnya kolaboratif antar Lembaga pemerintahan, swasta, masyarakat, dan akademisi. Namun data di lapangan menemukan beberapa kendala seperti proporsi penduduk Indonesia yang berpendidikan tinggi masih sedikit, ketidak sesuaian lulusan dengan lapangan pekerjaan, produktivitas tenaga kerja masih perlu ditingkatkan. Oleh karena itu perlu strategi pendekatan Human Capital Development untuk meningkatkan kaitannya tenaga kerja di public sector dan private sector melalui Human Capital Development Plan (HCDP), Critial Occupation List (COL) hingga enhance talent pipeline, promote talent diversity dan facilitate Talent Mobility.

Rencana Pemerintah untuk peningkatan pembangunan, merencanakan ada 7 agenda pembangunan di RPJMN 2020-2024, salah satunya peningkatan sumber daya manusia yang berkualitas dan berdaya saing. Kerangka pembangunan manusia yang berkualitas dan berdaya saing meliputi sehat, cerdas, adaptif, kreatif, inovatif, terampil dan bermartambat. Implementasi dari kerangka ini, dimulai dengan layanan dasar dan perlindungan sosial, lalu produktivitas hingga pembangunan karakter, menuju pertumbuhan penduduk yang seimbang.

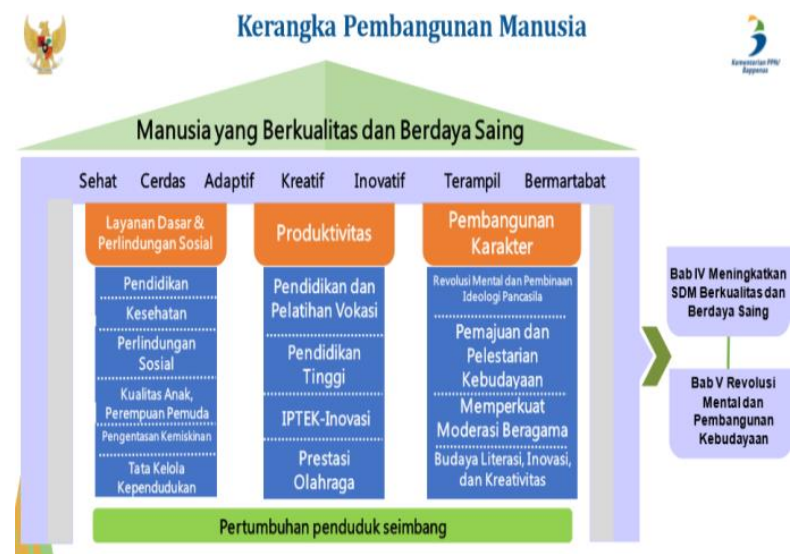

Gambar 2. Skema Kerangka Pembangunan Manusia

Collaborative Strategic Management perlu dilakukan sinergi antar pemangku kepentingan, sehingga peningkatan daya saing SDM melalui peningkatan produktivitas dapat tercapai, seperti pelibatan industri dalam pengembangan vokasi, peningkatan relevansi dan daya saing pendidikan tinggi, serta penguasaan adoposi teknologi dan menciptakan inovasi. Selain direncanakannya kolaborasi dalam peningkatan produktivitas perlu juga mendukung kebijakan dan strategis pendidikan dan pelatihan vokasi industri, salah satunya pengembangan keahlian, penyediaan fasilitas pendidikan, sertifikasi dan pendidikan kewirausahaan. Collaborative Strategic Management diperlukan untuk 


\section{SULTANIST: Jurnal Manajemen dan Keuangan, Vol 8 (1), 2020}

mendukung 2 arah kebijakan dan strategi yaitu penguatan pendidikan tinggi berkualitas dan arah kebijakan dan strategi untuk penguatan iptek. Hal ini mendorong kolaborasi antara perguruan tinggi dengan dunia industri dalam jangka panjang dan mendapatkan win-win solution bagi kedua belah pihak. Penelitianpenelitian dalam perguruan tinggi harus dikerahkan untuk menopang upaya penguasaan teknologi yang bermanfaat bagi rakyat banyak. Dunia pendidikan sebagai pencetak SDM berkualitas serta tempat lahirnya inovasi haruslah menjadi key driver dalam menolong industri untuk meningkatkan produksi secara efisien dan berkelanjutan.

\section{KESIMPULAN DAN SARAN}

Kesimpulan dari penelitian ini adalah dalam meningkatkan SDM menjadi Human Capital perlu sebuah model pola kemitraan yang melibatkan pemangku kepentingan seperti pihak industri, lembaga pendidikan dan pemerintah untuk mencapai tujuan yang kolektif dan maju bersama, hal ini merupakan bagian dari collaborative strategic management. Rekomendasi model collaborative strategic management merupakan fenomena baru dalam dunia pendidikan, industri maupun pemerintah. Faktor keberhasilan dari model ini adalah keterbukaan, transparansi, tanggung jawab atas pemikiran masing-masing pihak yang terintegrasi dalam jangka panjang. Dimana para pihak memiliki tanggung jawab masingmasing dalam menjalankan model pengembangan SDM menjadi Human Capital untuk mendukung pertumbuhan ekonomi Indonesia dimasa yang akan datang.

Adapun saran dari hasil penelitian ini adalah perlu dilanjutkan penelitian ini dengan implementasi pada kasus tertentu yang berkaitan dengan persoalan SDM sehingga dapat lebih fokus dan mendalam. Rekomendasi dari hasil penelitian ini adalah collaborative strategic management menjadi titik temu dalam mensinergikan arah dan kebijakan yang dikeluarkan oleh pemerintah, dan siap didukung oleh pemangku kepentingan sehingga target-target dapat tercapai melalui kebersamaan.

\section{DAFTAR PUSTAKA}

Allen, P. L. (2015). Toward a new HR philosophy. Retrieved January 8, 2020, from McKinsey Quarterly website: https://www.mckinsey.com/businessfunctions/organization/ourinsights/toward-a-new-hr-philosophy

Armstrong, M. (2008). Strategic human resource management: A guide to action (4th ed.). Philadelphia: Kogan Page.

Badan Pusat Statistik. (2017). Statistik Indonesia 2017. Retrieved from https://www.bps.go.id/publication/downlo ad/

Carmeli, A., \& Schaubroeck, J. (2005). How leveraging human resource capital with its competitive distinctiveness enhances the performance of commercial and public organizations. Human Resource Management, 44(4), 391-412. https://doi.org/10.1002/hrm.20081

Cheng, E. W. L., Li, H., \& Love, P. E. D. (2000). Establishment of Critical Success Factors for Construction Partnering. Journal of Management in Engineering, $16(2)$, 84-92. https://doi.org/10.1061/(ASCE)0742597X(2000)16:2(84)

Hendricks, L. (2002). How important is human capital for development? evidence from immigrant earnings. American Economic Review, 92(1), 198-219. https://doi.org/10.1257/00028280276001 5676

Koschatzky, K., \& Stahlecker, T. (2010). New forms of strategic research collaboration between firms and universities in the German research system. International Journal of Technology Transfer and Commercialisation, $9(1 / 2), \quad 94$. https://doi.org/10.1504/IJTTC.2010.0294 27

Menzies, M. (2003). Human capital development in research, science and technology. Retrieved from http://citeseerx.ist.psu.edu/viewdoc/downl oad?doi=10.1.1.199.9892\&rep=rep1\&typ $\mathrm{e}=\mathrm{pdf}$

Namasivayam, K., \& Denizci, B. (2006). Human capital in service organizations: 


\section{SULTANIST: Jurnal Manajemen dan Keuangan, Vol 8 (1), 2020}

identifying value drivers. Journal of Intellectual Capital, 7(3), 381-393. https://doi.org/10.1108/14691930610681 465

Piketty, T. (2014). Capital in the twenty-first century. Cambridge: Harvard University Press.

Sugiyono. (2017). Metode Penelitian Kuantitatif, Kualitatif, dan $R \& D$. Bandung: Alfabeta.

Suwardana, H. (2018). Revolusi industri 4.0 berbasis revolusi mental. JATI UNIK: Jurnal Ilmiah Teknik Dan Manajemen Industri, $\quad 1(1), \quad 102$. https://doi.org/10.30737/jatiunik.v1i2.11 7

Weatherly, L. (2003). Human capital - The elusive asset measuring and managing human capital: a strategic imperative for HR. Retrieved January 11, 2020, from Research Quarterly website: http://citeseerx.ist.psu.edu/viewdoc/down load?doi=10.1.1.490.188\&rep=rep1\&typ $\mathrm{e}=\mathrm{pdf}$

Wheelen, T. L., \& Hunger, J. D. (2012). Strategic management and business policy: toward global sustainability (13th ed.). New Jersey: Pearson Prentice Hall.

\section{Profil Singkat}

Maria Apsari Sugiat, Lahir di Jakarta pada tanggal 03 April 1978. Menyelesaikan S1 Program Akuntansi dan sempat menjadi Senior Auditor di KAP Grant Thornton, Jakarta. Lulus S2 Magister Manajemen di Unpad dan Lulus S3 Program Doktor Ilmu Manajemen Bisnis Unpad. Pernah mengajar Manajemen Desain di Universitas Maranatha serta pernah mengajar di Fakultas Industri Kreatif, Telkom University. Saat ini penulis adalah pengajar tetap di Fakultas Ekonomi Bisnis, Telkom University dengan bidang keahlian Strategik Manajemen. Pengalamannya di dunia broadcasting selama 15 tahun menjadi penyiar radio dan reporter di Radio Ardan Group Bandung, membawa pengalaman untuk mengembangkan kegiatan- kegiatan mahasiswa melalui entrepreneurship berbasis digital, penelitian UMKM dan meneliti sosial innovation. 